Article

\title{
Activity of Anthracenediones and Flavoring Phenols in Hydromethanolic Extracts of Rubia tinctorum against Grapevine Phytopathogenic Fungi
}

\author{
Natalia Langa-Lomba ${ }^{1,2}$, Eva Sánchez-Hernández ${ }^{3}$ (D) , Laura Buzón-Durán ${ }^{3}$, Vicente González-García ${ }^{2}$, \\ José Casanova-Gascón ${ }^{1}\left(\mathbb{D}\right.$, Jesús Martín-Gil ${ }^{3} \mathbb{D}$ and Pablo Martín-Ramos ${ }^{1, *(1)}$ \\ 1 Instituto Universitario de Investigación en Ciencias Ambientales de Aragón (IUCA), EPS, Universidad de \\ Zaragoza, Carretera de Cuarte, s/n, 22071 Huesca, Spain; natalialangalomba@gmail.com (N.L.-L.); \\ jcasan@unizar.es (J.C.-G.) \\ 2 Agrifood Research and Technology Centre of Aragón, Plant Protection Unit, Instituto Agroalimentario de \\ Aragón-IA2 (CITA-Universidad de Zaragoza), Avda. Montañana 930, 50059 Zaragoza, Spain; \\ vgonzalezg@aragon.es \\ 3 Department of Agricultural and Forestry Engineering, ETSIIAA, Universidad de Valladolid, \\ 34004 Palencia, Spain; eva.sanchez.hernandez@uva.es (E.S.-H.); laura.buzon@uva.es (L.B.-D.); \\ mgil@iaf.uva.es (J.M.-G.) \\ * Correspondence: pmr@unizar.es
}

Citation: Langa-Lomba, N.;

Sánchez-Hernández, E.;

Buzón-Durán, L.; González-García, V.; Casanova-Gascón, J.; Martín-Gil, J.; Martín-Ramos, P. Activity of Anthracenediones and Flavoring Phenols in Hydromethanolic Extracts of Rubia tinctorum against Grapevine Phytopathogenic Fungi. Plants 2021, 10, 1527. https://doi.org/10.3390/ plants10081527

Academic Editors: Dragana Šunjka and Špela Mechora

Received: 8 July 2021

Accepted: 23 July 2021

Published: 26 July 2021

Publisher's Note: MDPI stays neutral with regard to jurisdictional claims in published maps and institutional affiliations.

Copyright: (c) 2021 by the authors. Licensee MDPI, Basel, Switzerland. This article is an open access article distributed under the terms and conditions of the Creative Commons Attribution (CC BY) license (https:/ / creativecommons.org/licenses/by/ $4.0 /)$.

\begin{abstract}
In this work, the chemical composition of Rubia tinctorum root hydromethanolic extract was analyzed by GC-MS, and over 50 constituents were identified. The main phytochemicals were alizarin-related anthraquinones and flavoring phenol compounds. The antifungal activity of this extract, alone and in combination with chitosan oligomers (COS) or with stevioside, was evaluated against the pathogenic taxa Diplodia seriata, Dothiorella viticola and Neofusicoccum parvum, responsible for the so-called Botryosphaeria dieback of grapevine. In vitro mycelial growth inhibition tests showed remarkable activity for the pure extract, with $\mathrm{EC}_{50}$ and $\mathrm{EC}_{90}$ values as low as 66 and $88 \mu \mathrm{g} \cdot \mathrm{mL}^{-1}$, respectively. Nonetheless, enhanced activity was attained upon the formation of conjugate complexes with COS or with stevioside, with synergy factors of up to 5.4 and 3.3, respectively, resulting in $\mathrm{EC}_{50}$ and $\mathrm{EC}_{90}$ values as low as 22 and $56 \mu \mathrm{g} \cdot \mathrm{mL}^{-1}$, respectively. The conjugate with the best performance (COS-R. tinctorum extract) was then assayed ex situ on autoclaved grapevine wood against $D$. seriata, confirming its antifungal behavior on this plant material. Finally, the same conjugate was evaluated in greenhouse assays on grafted grapevine plants artificially inoculated with the three aforementioned fungal species, resulting in a significant reduction in the infection rate in all cases. This natural antifungal compound represents a promising alternative for developing sustainable control methods against grapevine trunk diseases.
\end{abstract}

Keywords: antifungal; Botryosphaeriaceae; chitosan; GTDs; madder; stevioside; Vitis vinifera

\section{Introduction}

The joint presence of compounds of quinone and phenol categories in plant extracts and, specifically, the differential content of anthracenediones and 4-tert-butyl-2-phenylphenol, which might be responsible for the chromatic aberration of teak (difference between heartwood and sapwood), has been the object of attention in the bibliography [1].

Anthracenediones are a class of molecules based on the 9,10-anthracenedione parent (Figure 1a), which-among others-include purpurin (Figure 1a) and those synthesized by the American Cyanamid Laboratories in the late 1970s [2]. Although mitoxantrone, which has a dihydroxyanthraquinone central chromophore with two symmetrical aminoalkyl side chains (Figure 1a), is considered the biologically most active anthracenedione [3], other anthracenediones have also been reported to have antimicrobial activities: for instance, anthraquinone aglycones have been found to have a remarkable in vitro activity 
against clinical strains of dermatophytes [4]; anthraquinone derivatives exhibit antifungal activity against Candida albicans (C.P. Robin) Berkhout, Cryptococcus neoformans (San Felice) Vuill., Trichophyton mentagrophytes (C.P. Robin) R. Blanch., Aspergillus fumigatus Fresen. and Sporothrix schenckii Hektoen and C.F. Perkins [5,6]; purpurin possesses remarkable antifungal activity against Candida spp. [7]; and alizarin or 1,2-dihydroxyanthraquinone (Figure 1b) show antifungal behavior against Aspergillus niger Tieghem and A. ochraceus $\mathrm{K}$. Wilhelm [8].

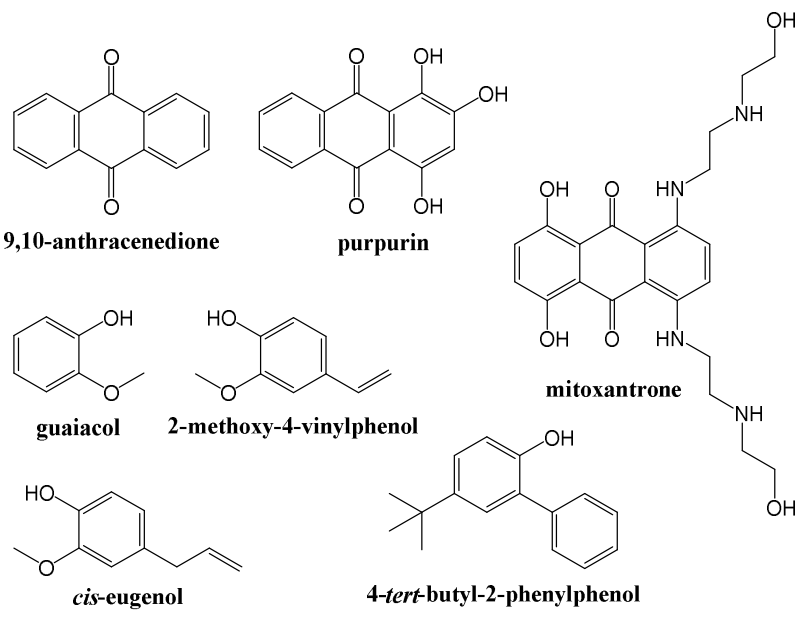

(a)
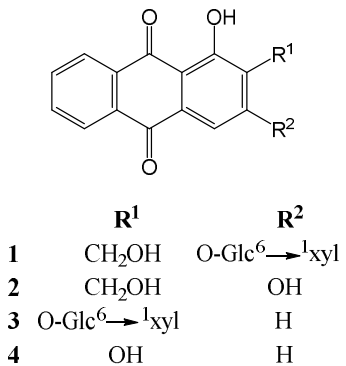

(b)

Figure 1. (a) Structures of different anthracenediones and phenols; (b) structures of alizarin-3-O- $\beta$ primeveroside, 3; lucidin-3-O- $\beta$-primeveroside, 1 ; and their aglycons (alizarin, 4; lucidin, 2). Glc, D-glucose; xyl, D-xylose.

Flavoring phenols is a category that includes small free phenolic compounds (Figure 1a), such as 2-methoxy-phenol (or guaiacol), 2-methoxy-4-vinylphenol (or 4-vinyl-guaiacol), cis-2-methoxy -4-(1-propenyl)-phenol (or cis-eugenol) and 4-tert-butyl-2-phenyl-phenol, which participate in the aroma of wine. Guaiacol and eugenol are characterized by spice, clove, and smoke notes (guaiacol provides a roasted aroma and eugenol confers a clove aroma); and 4-vinyl-guaiacol has an odor reminiscent of carnation (Dianthus flowers). 4-((1E)-3-hydroxy-1-propenyl)-2-methoxyphenol (or coniferyl alcohol) is a precursor of grape and wine volatiles [9]. All of them are present in oak, but 4-tert-butyl-2-phenylphenol has been referred as a constituent of Rubia cordifolia L. essential oil [10,11]. Regarding their antifungal activities, a strong antifungal activity against Botrytis cinerea Pers. has been referred for eugenol [12], and guaiacol has been found to be effective against sap-staining fungi (Ophiostoma spp.) [13].

In this paper, the possibility of a joint presence of both anthracenediones and flavoring phenols in Rubia tinctorum L. (Rubiaceae) has been explored, given that the presence of 9,10-anthraquinones and other biologically active compounds has been reported for other members of the genus Rubia, mainly for $R$. cordifolia, as summarized in the review paper by Singh, et al. [14].

$R$. tinctorum is widely distributed in southern and southeastern Europe, in the Mediterranean area, and in central Asia. Its reddish roots contain hydroxyanthraquinones, such as alizarin (used for the dyeing of textiles [15] and in the treatment of kidney and bladder stones), purpurin (1,2,4-trihydroxyanthraquinone), and lucidin (Figure 1b.4) [16,17]; and flavoring phenols such as 4-vinyl-guaiacol [18].

The interest in the joint presence of anthracenediones and phenols (as 2-methoxyphenols and 4-tert-butyl-2-phenyl-phenol) lies in the possibility of synergies that enhance their microbiological activity. In particular, this work focuses on their potential application for the control of grapevine trunk diseases (GTDs), currently considered one of the most relevant challenges in Viticulture, as these pathologies cause significant economic losses in 
grape growing areas all over the world. Under this generic concept, a series of mycoses are grouped, which affect the wood of grapevine throughout its entire life cycle $[19,20]$. Among them, those that affect young plants coming from the nursery and in the first years after planting are especially important from the economic point of view, being responsible for numerous losses derived from the removal and replacement of plants in hundreds of thousands of hectares around the world [21]. Some of these include the so-called "Black Foot" disease, caused by different species belonging to soil-borne genera like Ilyonectria, Campylocarpon, Cylindrocladiella, Dactylonectria, etc.; the etiological agents responsible for Petri disease (mainly species of the genus Phaeoacremonium, and Phaeomoniella chlamydospora (W. Gams, Crous, M.J. Wingf. and Mugnai) Crous and W. Gams) that for many authors would be part of the first stages of the complex esca syndrome; or some species of the ascomycete family Botryosphaeriaceae, especially certain aggressive taxa in the early years of the plant such as Neofusicoccum parvum (included in the present study). In addition to these pathologies, other complex syndromes have been described, such as the aforementioned esca (attributable to certain species of lignicolous basidiomycetes), Eutypiosis (caused in Europe by Eutypa lata (Pers.) Tul. and C. Tul.), or the so-called Botryosphaeria decay of grapevine plants (also known as "Black Dead Arm" disease) caused by various genera and species of this family such as the aforementioned N. parvum, Diplodia spp., Dothiorella spp., Lasiodiplodia spp. or Botryosphaeria spp.

Given that the prohibition of active ingredients such as sodium arsenite and benzimidazoles, which were used to control GTDs, has worsened the impact of these diseases, they have become the subject of intense research efforts. Unfortunately, due to the breadth and complexity of the problem, no single effective control measure against these mycoses has been developed to date. Current strategies and future prospects for the management of GTDs are thoroughly discussed in the review papers by Fontaine, et al. [22], Bertsch, et al. [20], Mondello, et al. [23] and Gramaje, et al. [24], but the use of active ingredients of natural origin, instead of conventional chemicals, poses an especially interesting approach, aligned with the criteria of European legislation currently in force (Article 14 in European Directive 2009/128/EC).

Taking into consideration that many phytochemicals have solubility and bioavailability problems, in this work the bioactivity of the hydromethanolic extracts of $R$. tinctorum against GTDs has also been assayed after the formation of conjugate complexes, either with chitosan oligomers (COS) or with stevioside [a terpene glycoside obtained from Stevia rebaudiana (Bertoni) Bertoni extract], which also have antifungal properties and which may lead to a synergistic fungicide behaviour [25,26].

\section{Material and Methods}

\subsection{Plant Material and Chemicals}

The specimens of Rubia tinctorum under study were collected on the banks of the Carrión river as it passes through the town of Palencia (Spain). The roots were shade-dried and pulverized to fine powder in a mechanical grinder. Samples from different specimens $(n=25)$ were thoroughly mixed to obtain composite samples.

Chitosan (CAS 9012-76-4; high MW: 310,000-375,000 Da) was supplied by Hangzhou Simit Chem. \& Tech. Co. (Hangzhou, China). Neutrase ${ }^{\mathrm{TM}} 0.8 \mathrm{~L}$ enzyme was supplied by Novozymes A/S (Bagsværd, Denmark). Stevioside (CAS 57817-89-7, 99\%) was purchased from Wako Chemicals GmbH (Neuss, Germany). Quantities of 4-tert-butyl-2-phenylphenol (CAS 98-27-1, 97\%), 1,2-dihydroxyanthraquinone (CAS 72-48-0, 97\%), sodium alginate (CAS 9005-38-3), calcium carbonate (CAS 471-34-1, $\geq 99.0 \%$ ) and methanol (CAS 67-561, UHPLC, suitable for mass spectrometry) were acquired from Sigma-Aldrich Química (Madrid, Spain). Agar (CAS 9002-18-0) and PDA (potato dextrose agar) were supplied by Becton Dickinson (Bergen County, NJ, USA). 


\subsection{Preparation and Physicochemical Characterization of the of $R$. tinctorum Extracts}

Rubia tinctorum samples were mixed $(1: 20, w / v)$ with a methanol/water solution (1:1 $v / v$ ) and heated in a water bath at $50^{\circ} \mathrm{C}$ for $30 \mathrm{~min}$, followed by sonication for $5 \mathrm{~min}$ in pulse mode with a $1 \mathrm{~min}$ stop for each $2.5 \mathrm{~min}$, using a $1000 \mathrm{~W}$ probe-type ultrasonicator operated at $20 \mathrm{kHz}$ (model UIP1000hdT, Hielscher Ultrasonics, Teltow, Germany). The solution was then centrifuged at $9000 \mathrm{rpm}$ for $15 \mathrm{~min}$ and the supernatant was filtered through Whatman No. 1 paper. Aliquots were lyophilized for the vibrational spectroscopy analysis.

The infrared vibrational spectra of both dried and ground roots and the lyophilized extract were registered using a Thermo Scientific (Waltham, MA, USA) Nicolet iS50 Fouriertransform infrared spectrometer, equipped with an in-built diamond attenuated total reflection (ATR) system. The spectra were collected with a $1 \mathrm{~cm}^{-1}$ spectral resolution over the $400-4000 \mathrm{~cm}^{-1}$ range, taking the interferograms that resulted from co-adding 64 scans. The spectra were then corrected using the advanced ATR correction algorithm [27] available in OMNIC ${ }^{\mathrm{TM}}$ software suite.

The hydroalcoholic plant extract was studied by gas chromatography-mass spectrometry (GC-MS) at the Research Support Services (STI) at Universidad de Alicante (Alicante, Spain), using a gas chromatograph model 7890A coupled to a quadrupole mass spectrometer model 5975C (both from Agilent Technologies). The chromatographic conditions were: 3 injections $/$ vial, injection volume $=1 \mu \mathrm{L}$; injector temperature $=280^{\circ} \mathrm{C}$, in splitless mode; initial oven temperature $=60^{\circ} \mathrm{C}, 2 \mathrm{~min}$, followed by ramp-up of $10^{\circ} \mathrm{C} / \mathrm{min}$ to a final temperature of $300{ }^{\circ} \mathrm{C}, 15 \mathrm{~min}$. The chromatographic column used for the separation of the compounds was an Agilent Technologies HP-5MS UI of $30 \mathrm{~m}$ length, $0.250 \mathrm{~mm}$ diameter and $0.25 \mu \mathrm{m}$ film. The mass spectrometer conditions were: temperature of the electron impact source of the mass spectrometer $=230^{\circ} \mathrm{C}$ and of the quadrupole $=150{ }^{\circ} \mathrm{C}$; ionization energy $=70 \mathrm{eV}$. Test mixture 2 for apolar capillary columns according to Grob (Supelco 86501) and PFTBA tuning standards were used for equipment calibration. NIST11 library and the monograph by Adams [28] were used for compound identification.

\subsection{Preparation of Chitosan Oligomers and Bioactive Formulations}

Chitosan oligomers (COS) were prepared according to the procedure reported by Santos-Moriano, et al. [29], with the modifications indicated in [30], obtaining oligomers with a molecular weight $<2000 \mathrm{Da}$.

The COS-R. tinctorum and stevioside- $R$. tinctorum conjugate complexes were obtained by mixing the respective solutions in a 1:1 $(v / v)$ ratio. The mixtures were then sonicated for $15 \mathrm{~min}$ in five 3-minute periods (so that the temperature did not exceed $60^{\circ} \mathrm{C}$ ) using a probe-type ultrasonicator.

For the assays carried out on autoclaved wood, the conjugate complex was dispersed in an agar matrix (15 g/L in Milli-Q water), using a procedure analogous to the one described below for the in vitro tests.

For the in vivo assays, the bioactive product was dispersed in a calcium alginate matrix. Hydrogel beads were prepared as follows: the control product was added to a $3 \%$ sodium alginate solution in a 2:8 ratio ( $20 \mathrm{~mL}$ compound $/ 80 \mathrm{~mL}$ sodium alginate). Subsequently, this solution was dispensed drop by drop onto a $3 \%$ calcium carbonate solution to polymerize ( $30 \mathrm{~min}$ curing), obtaining beads with diameters in the $4-6 \mathrm{~mm}$ range.

\subsection{Fungal Isolates}

The three fungal isolates used (Table 1) were supplied as lyophilized vials (later reconstituted and refreshed as PDA subcultures) by the Agricultural Technological Institute of Castilla and Leon (ITACYL, Valladolid, Spain) [31]. 
Table 1. Fungal isolates used in the study.

\begin{tabular}{|c|c|c|c|c|}
\hline Code & Isolate & Binomial Nomenclature & Geographical Origin & Host/Date \\
\hline ITACYL_F098 & Y-084-01-01a & Diplodia seriata De Not. & $\begin{array}{c}\text { Spain } \\
\text { (DO Toro) }\end{array}$ & $\begin{array}{c}\text { Grapevine } \\
\text { ('Tempranillo') } 2004\end{array}$ \\
\hline ITACYL_F118 & Y-103-08-01 & $\begin{array}{l}\text { Dothiorella viticola } \\
\text { A.J.L.Phillips and J.Luque } \\
\text { Neofusicoccum parvum }\end{array}$ & $\begin{array}{c}\text { Spain } \\
\text { (Extremadura) }\end{array}$ & $\begin{array}{c}\text { Grapevine } \\
2004\end{array}$ \\
\hline ITACYL_F111 & Y-091-03-01c & $\begin{array}{c}\text { (Pennycook and Samuels) } \\
\text { Crous, Slippers and } \\
\text { A.J.L.Phillips }\end{array}$ & $\begin{array}{c}\text { Spain } \\
\text { (Navarra, nursery) }\end{array}$ & $\begin{array}{c}\text { Grapevine } \\
\text { ('Verdejo') } 2006\end{array}$ \\
\hline
\end{tabular}

\subsection{Antifungal Activity Assessment}

\subsubsection{In vitro Tests of Mycelial Growth Inhibition}

The antifungal activity of the different treatments was determined using the agar dilution method according to EUCAST standard antifungal susceptibility testing procedures [32], by incorporating aliquots of stock solutions onto the PDA medium to obtain concentrations in the $15.62-1500 \mu \mathrm{g} \cdot \mathrm{mL}^{-1}$ range. Mycelial plugs $(\varnothing=5 \mathrm{~mm})$ from the margin of 1-week-old PDA cultures of D. seriata, D. viticola or N. parvum were transferred to plates incorporating the above-mentioned concentrations for each treatment ( 3 plates per treatment/concentration, with 2 replicates each). Plates were then incubated at $25^{\circ} \mathrm{C}$ in the dark for a week. PDA medium without any amendment was used as control. Mycelial growth inhibition was estimated according to the formula: $\left(\left(d_{c}-d_{t}\right) / d_{c}\right) \times 100$, where $d_{c}$ and $d_{t}$ represent the average diameters of the fungal colony of the control and of the treated fungal colony, respectively. Effective concentrations $\left(\mathrm{EC}_{50}\right.$ and $\left.\mathrm{EC}_{90}\right)$ were estimated using PROBIT analysis in IBM SPSS Statistics v.25 (IBM; Armonk, NY, USA) software. The level of interaction (i.e., synergy factors) was determined according to Wadley's method [33].

\subsubsection{Assays on Autoclaved Grape Wood}

The formulation (COS-R. tinctorum conjugate) that showed the best performance in the in vitro assays was then tested on autoclaved grapevine wood to assess its behaviour on plant material against the least sensitive fungus in the previous plate tests. One-year-old dormant canes (Vitis vinifera L. cv. 'Tempranillo') were cut into $16 \mathrm{~cm}$ (length) and $0.8-1 \mathrm{~cm}$ (diameter) segments and autoclaved twice at $121^{\circ} \mathrm{C}(20 \mathrm{~min})$ to eliminate any microbial contamination. Inoculation was performed by first making two approximately $3 \mathrm{~mm}$ deep slits with a scalpel (without reaching the medullary tissue) per shoot, $8-10 \mathrm{~cm}$ apart and located in the internodes. A $3 \mathrm{~mm}$ diameter plug of PDA agar coming from the margin of a 10-day colony of the pathogen $(D$. seriata) was placed in each slit, flanked by 2 plugs $(\varnothing=3 \mathrm{~mm})$ of bacteriological agar that contained the tested conjugate complex. After this, the wounds were covered with autoclaved cotton moistened with sterile bi-distilled water and sealed with Parafilm ${ }^{\mathrm{TM}}$ tape. Inoculated shoots were placed in transparent culture boxes on a bed of sterile filter paper, periodically moistened (with sterile double distilled water), and incubated for 21 days in a climatic chamber at $26^{\circ} \mathrm{C}$, with $70 \% \mathrm{RH}$ and a 12/12 h photoperiod. A total of 5 boxes with 3 replicates/box each were arranged, together with a positive control inoculated only with $D$. seriata ( 1 box with 3 replicates) and a negative control without pathogen, inoculated only with the conjugate (also 1 box with 3 replicates).

After the incubation period, segments were recovered from the boxes, and each of them was divided into two halves of approximately $8 \mathrm{~cm}$, before longitudinal cuts were made in each half. Finally, the length of the vascular necroses produced was measured longitudinally on upper and lower directions from the inoculation point for both halves, and compared with those of controls. 


\subsubsection{Greenhouse Bioassays on Grafted Plants}

Bioassays with COS (chosen as a reference) and COS-R. tinctorum conjugate complexes were performed in living plants in order to scale the protective capabilities of these compounds against the three selected Botryosphaeriaceae species in young grapevine plants. As summarized in Table S1, plant material consisted of 30 plants of 'Tempranillo' (CL. 32 clone) (2 year old) cultivar and 30 plants of 'Garnacha' (VCR3 clone) (1 year old) cultivar, grafted on $775 \mathrm{P}$ and $110 \mathrm{R}$ rootstocks, respectively. Each plant was cultured on a 3.5 L plastic pot containing a mixed substrate of moss peat and sterilized natural soil (75:25), incorporating slow release fertilizer when needed along the culture cycle. Plants were maintained in the greenhouse with drip irrigation and anti-weed ground cover from June to December 2020 (6 months). One week after placing them in pots, young, grafted plants were artificially inoculated with the pathogens and the COS-R. tinctorum treatment. Five repetitions (plants) were arranged for each pathogen*cultivar combination, together with 4 positive controls/(pathogen*cultivar) plus 3 negative controls (incorporating only the bioactive product) for each cultivar. Inoculations of both pathogens and the control product were carried out directly on the trunk of the living plants at two sites per stem (separated $>5 \mathrm{~cm}$ ) below the grafting point and not reaching the root crown. For the different fungi, agar plugs from the margin of 5 day old fresh PDA cultures of each species were used as fungal inoculum. In the aforementioned two inoculation points of each grapevine plant, slits of approx. $15 \mathrm{~mm}$ in diameter and $5 \mathrm{~mm}$ deep were made with a scalpel. Subsequently, $5 \mathrm{~mm}$ diameter agar plugs were placed directly into contact with vascular tissue in the stem; simultaneously, calcium alginate hydrogel beads containing the bioactive product were placed at both sides of the agar plug; and the whole set was covered with cotton soaked in sterile bi-distilled water and sealed with Parafilm ${ }^{\mathrm{TM}}$ tape. During the culture period, application of copper (cuprous oxide $75 \%$, Cobre Nordox ${ }^{\mathrm{TM}}$ $75 \mathrm{WG}$ ) to control downy mildew outbreaks was performed in mid-July, accompanied with a first sprouting (followed by periodic sprouting). Plants were visually examined weekly for the presence of foliar symptoms. After six months in the greenhouse, the plants were removed, two sections of the inoculated stems between the grafting point and the root crown were prepared and sectioned longitudinally. The length of the vascular necroses was scored longitudinally on upper and lower directions from the inoculation point for both halves of the longitudinal cut, and the average measures of these were statistically analysed and compared depending on the type of pathogen. All the data were compared with positive and negative controls. Finally, grapevine plants removed and measured at the end of the assay were also processed to re-isolate the different pathogenic taxa previously inoculated. Thus, $5 \mathrm{~mm}$ long wood chips exhibiting vascular necroses $(1-2 \mathrm{~cm}$ around the wounds) were washed, their surface sterilized, then placed in PDA plates amended with streptomycin sulphate (to avoid bacterial contamination) and incubated in a culture chamber at $26^{\circ} \mathrm{C}$ in the dark for $2-3$ days.

\subsection{Statistical Analyses}

The results of the in vitro inhibition of mycelial growth were statistically analyzed using one-way analysis of variance (ANOVA), followed by post hoc comparison of means through Tukey's test at $p<0.05$ (provided that the homogeneity and homoscedasticity requirements were satisfied, according to the Shapiro-Wilk and Levene tests). In the case of autoclaved grapevine wood and greenhouse assay results, since the normality and homoscedasticity requirements were not met, the Kruskal-Wallis non-parametric test was used instead, with the Conover-Iman test for post hoc multiple pairwise comparisons. $\mathrm{R}$ statistical software was used for all the statistical analyses [34].

\section{Results}

\subsection{Vibrational Characterization}

The assignment of the main absorption bands in the infrared spectra of the R. tinctorum root powder and root extracts is shown in Table 2. The most prominent band, attributed to 
the benzene ring in aromatic compounds, occurs at ca. $1500 \mathrm{~cm}^{-1}$. The bands at $1592 \mathrm{~cm}^{-1}$ and $1676 \mathrm{~cm}^{-1}$ can be assigned to the in-phase $\mathrm{C}=\mathrm{O}$ and symmetrical $\mathrm{C}=\mathrm{C}$ vibrations from anthraquinone.

Table 2. Main bands in the infrared spectra of root and lyophilized R. tinctorum extract and of two of its main constituents.

\begin{tabular}{|c|c|c|c|c|}
\hline \multicolumn{2}{|c|}{ R. tinctorum } & \multirow{2}{*}{ Anthraquinone } & \multirow{2}{*}{$\begin{array}{l}\text { 4-tert-butyl-2- } \\
\text { phenylphenol }\end{array}$} & \multirow[t]{2}{*}{ Assignment } \\
\hline Root Powder & Extract & & & \\
\hline 3334 & 3335 & & & Bonded O-H stretching (cellulose) \\
\hline \multirow{4}{*}{2920} & & 2964 & & $\mathrm{sp}^{3} \mathrm{C}-\mathrm{H}$ \\
\hline & 2920 & 2925 & & $=\mathrm{C}-\mathrm{H}$ groups of aromatic rings \\
\hline & & 2856 & & aliphatic $\mathrm{C}-\mathrm{H}$ asymmetrical stretching \\
\hline & & 2724 & & $\begin{array}{l}\beta-\mathrm{OH} \text {, typical of } \alpha \text {-hydroxy } \\
\text { anthraquinone }\end{array}$ \\
\hline \multirow[t]{3}{*}{1727} & 1733 & & & $\mathrm{C}=\mathrm{O}$ from esters \\
\hline & & 1704 & & ester $\mathrm{C}=\mathrm{O}$ \\
\hline & & 1676 & & $\mathrm{C}=\mathrm{O}$ in anthraquinones \\
\hline 1639 & 1620 & 1633 & & $\mathrm{C}=\mathrm{O}$ in anthraquinones \\
\hline 1602 & 1605 & 1592 & 1585 & $\begin{array}{l}\text { phenyl ring (aromatic skeletal vibration) } \\
>\mathrm{C}=\mathrm{C}<\text { in anthraquinones }\end{array}$ \\
\hline \multirow[t]{4}{*}{1552} & & & 1545 & carboxylate stretches $/ \mathrm{C}=\mathrm{C}$ aromatic \\
\hline & 1511 & & 1480 & methylene $\mathrm{C}-\mathrm{H}$ bend \\
\hline & & 1461 & 1470 & methyl C-H asymmetrical \\
\hline & 1435 & & 1430 & $=\mathrm{C}-\mathrm{H}$ in plane bending \\
\hline \multirow[t]{2}{*}{1414} & 1416 & & 1420 & vinyl $\mathrm{C}-\mathrm{H}$ in plane bending \\
\hline & 1406 & 1377 & 1385 & C-C asymmetrical stretching \\
\hline \multirow{3}{*}{1370} & & & & \\
\hline & & & 1355 & $\begin{array}{l}\mathrm{C}-\mathrm{O} \text { stretching/methylene } \mathrm{C}-\mathrm{H} \\
\text { bending }\end{array}$ \\
\hline & & $\begin{array}{l}1333 \\
1329\end{array}$ & 1325 & $\begin{array}{l}\mathrm{C}-\mathrm{H} \text { in-plane deformation } \\
\text { methylene } \mathrm{C}-\mathrm{H} \text { bending }\end{array}$ \\
\hline 1316 & 1316 & 1306 & & vinylidene $\mathrm{C}-\mathrm{H}$ in plane bending \\
\hline \multirow[t]{6}{*}{1255} & 1255 & 1287 & 1270 & $\begin{array}{l}\mathrm{C}-\mathrm{O} \text { stretching } / \mathrm{C}=\mathrm{C} \\
\text { symmetric stretching }\end{array}$ \\
\hline & & 1207 & 1215 & $\mathrm{C}-\mathrm{O}$ stretching $/ \mathrm{C}-\mathrm{H}$ in plane bending \\
\hline & & 1171 & 1180 & $-\mathrm{C}-\mathrm{O}-\mathrm{C}-$ stretching \\
\hline & 1142 & 1153 & 1135 & \\
\hline & 1100 & 1099 & & \\
\hline & & 1087 & 1080 & \\
\hline \multirow[t]{2}{*}{1020} & & & 1025 & $\mathrm{C}-\mathrm{C}$ stretching \\
\hline & 951 & 969 & & $\mathrm{C}-\mathrm{H}$ out-of-plane bending \\
\hline
\end{tabular}

\subsection{Gas Chromatography-Mass Spectrometry Analysis of the Extract}

In R. tinctorum root hydromethanolic extracts, the main analyzed components (Table 3) were: the anthraquinone family $(19.4 \%)$ consisting of 2-methyl-9,10-anthracenedione (or $\beta$-methylanthraquinone) (15.5\%), 1,2-dihydroxyanthraquinone (or alizarin), 1,8-dihydroxy-3methylanthraquinone, 1-hydroxy-9,10-anthracenedione (or $\alpha$-hydroxyanthraquinone) and 1-hydroxy-4-methylanthraquinone; cyclopentenones (2.3\%), such as 2-hydroxy-2-cyclopenten- 
1-one and 4-cyclopentene-1,3-dione; and the phenol category (7.5\%), constituted by cis-2methoxy-4-(1-propenyl)-phenol (or cis-eugenol), 2-methoxy-phenol (or guaiacol), 2-methoxy4-vinylphenol (or 4-vinyl-guaiacol), 4-tert-butyl-2-phenylphenol, and coniferyl alcohol. Other phytochemicals of interest were 4-methoxy-4',5'-methylenedioxybiphenyl-2-carboxylic acid (8.6\%), 1,4-diacetyl-3-acetoxymethyl-2,5-methylene-1-rhamnitol (8.3\%) and guanosine (5.8\%).

Table 3. Phytochemicals identified in R. tinctorum root hydromethanolic extract by GC-MS.

\begin{tabular}{|c|c|c|c|}
\hline Peak & $\mathbf{R}_{\mathbf{t}}(\min )$ & Area $(\%)$ & Assignments \\
\hline 1 & 4.6369 & 1.99 & 4-pentenoic acid, ethyl ester \\
\hline 2 & 4.7440 & 0.26 & 1-gala-1-ido-octose \\
\hline 3 & 4.8414 & 0.52 & 4-cyclopentene-1,3-dione \\
\hline 4 & 5.0021 & 1.09 & oxime-, methoxy-phenyl- \\
\hline 5 & 5.1968 & 0.46 & 1-(2-furanyl)-ethanone \\
\hline 6 & 5.2942 & 1.36 & 2,5-diethenyltetrahydro-2-methyl-furan \\
\hline 7 & 5.3770 & 1.82 & 2-hydroxy-2-cyclopenten-1-one \\
\hline 8 & 6.0781 & 0.70 & 2,4-dihydroxy-2,5-dimethyl-3(2H)-furan-3-one \\
\hline 9 & 6.3312 & 2.91 & 2-hydroxy- $\gamma$-butyrolactone \\
\hline 10 & 6.6331 & 2.47 & glycerin \\
\hline 11 & 6.7694 & 1.93 & 1,2-cyclopentanedione, 3-methyl- \\
\hline 12 & 6.9690 & 1.19 & 2-acetamido-2-deoxy- $\alpha$-D-glucopyranose \\
\hline 13 & 7.1345 & 0.76 & butyronitrile, 4-ethoxy-3-hydroxy- \\
\hline 14 & 7.2952 & 1.55 & 2,5-dimethyl-4-hydroxy-3(2H)-furanone \\
\hline 15 & 7.4267 & 0.77 & trimethyl(tetrahydrofuran-2-ylperoxy)silane \\
\hline 16 & 7.6798 & 1.01 & 2-methoxy-phenol (or guaiacol) \\
\hline 17 & 7.7869 & 2.20 & L-alanine, methyl ester \\
\hline 18 & 8.2008 & 2.65 & dimethyl dl-malate \\
\hline 19 & 8.3955 & 0.64 & ethanamine, N-ethyl-N-nitroso- \\
\hline 20 & 8.5270 & 2.47 & 4H-pyran-4-one, 2,3-dihydro-3,5-dihydroxy-6-methyl- \\
\hline 21 & 9.1453 & 0.87 & 4H-pyran-4-one, 3,5-dihydroxy-2-methyl- \\
\hline 22 & 9.2865 & 0.97 & catechol \\
\hline 23 & 9.4471 & 0.94 & 1,4:3,6-dianhydro- $\alpha$-d-glucopyranose \\
\hline 24 & 9.6857 & 0.35 & 5-hydroxymethylfurfural \\
\hline 25 & 10.3965 & 0.31 & 2-acetoxy-5-hydroxyacetophenone \\
\hline 26 & 10.5718 & 0.50 & p-cymen-7-ol \\
\hline 27 & 10.8882 & 2.80 & 2-methoxy-4-vinylphenol (or 4-vinylguaiacol) \\
\hline 28 & 11.2193 & 0.98 & DL-arabinose \\
\hline 29 & 11.7451 & 1.09 & DL-proline, 5-oxo-, methyl ester \\
\hline 30 & 12.0470 & 0.74 & vanillin \\
\hline 31 & 12.6702 & 1.96 & 2-methoxy-4-(1-propenyl)-phenol (Z)- (or cis-isoeugenol) \\
\hline 32 & 13.1473 & 1.05 & 1-[4-(methylthio)phenyl]-ethanone \\
\hline 33 & 13.4492 & 0.86 & butylated hydroxytoluene \\
\hline 34 & 13.6877 & 0.57 & benzeneacetic acid, 4-hydroxy-3-methoxy-, methyl ester \\
\hline 35 & 13.9458 & 0.82 & 1,4-diacetyl-3-acetoxymethyl-2,5-methylene-1-rhamnitol \\
\hline 36 & 14.3693 & 2.44 & $\alpha$-methyl-1-sorboside \\
\hline 37 & 15.0461 & 5.78 & guanosine \\
\hline 38 & 15.5865 & 8.31 & 1,4-diacetyl-3-acetoxymethyl-2,5-methylene-1-rhamnitol \\
\hline 39 & 16.0734 & 1.65 & $\begin{array}{l}\text { 4-((1E)-3-hydroxy-1-propenyl)-2-methoxyphenol (or } \\
\text { coniferyl alcohol) }\end{array}$ \\
\hline 40 & 17.4561 & 0.43 & $\begin{array}{l}\text { 5-amino-1-(4-amino-furazan-3-yl)-1H-[1-3]triazole-4- } \\
\text { carbonitrile }\end{array}$ \\
\hline 41 & 17.9088 & 1.18 & hexadecanoic acid, methyl ester \\
\hline 42 & 18.2594 & 1.17 & n-hexadecanoic acid \\
\hline 43 & 19.1552 & 0.76 & $\begin{array}{l}\text { 5-(1,1-dimethylethyl)[1,1'-biphenyl]-2-ol (or } \\
\text { 4-tert-butyl-2-phenylphenol) }\end{array}$ \\
\hline 45 & 19.4278 & 0.69 & cyclopentadecane \\
\hline 46 & 19.6421 & 0.15 & $\begin{array}{c}\text { 1-hydroxy-9,10-anthracenedione (or } \\
\alpha \text {-hydroxyanthraquinone) }\end{array}$ \\
\hline 47 & 19.8709 & 15.54 & 9,10-anthracenedione, 2 -methyl- (or $\beta$-methylanthraquinone) \\
\hline 48 & 20.7278 & 1.43 & 1-hydroxy-4-methylanthraquinone \\
\hline 49 & 21.1659 & 1.75 & 1,2-dihydroxyanthraquinone (or alizarin) \\
\hline
\end{tabular}


Table 3. Cont.

\begin{tabular}{|c|c|c|c|}
\hline Peak & $\mathbf{R}_{t}(\min )$ & Area $(\%)$ & Assignments \\
\hline 50 & 21.8038 & 1.40 & azacyclotridecan-2-one, 1-(3-aminopropyl)- \\
\hline 51 & 23.0550 & 0.81 & glycerol 1-palmitate \\
\hline 52 & 23.3812 & 0.73 & bis(2-ethylhexyl) phthalate \\
\hline 53 & 23.8973 & 0.24 & $\begin{array}{l}\text { 1,8-dihydroxy-3-methyl-9,10-anthracenedione (or } \\
\text { 1,8-dihydroxy-3-methyl anthraquinone) }\end{array}$ \\
\hline 54 & 24.2673 & 8.57 & 4-methoxy-4 $4^{\prime}, 5^{\prime}$-methylenedioxybiphenyl-2-carboxylic acid \\
\hline 55 & 24.4474 & 0.42 & $\begin{array}{l}\text { 9-octadecenoic acid (Z)-, } \\
\text { 2-hydroxy-1-(hydroxymethyl)ethyl ester }\end{array}$ \\
\hline 56 & 25.4260 & 0.35 & squalene \\
\hline 57 & 29.2333 & 0.62 & $\begin{array}{c}\text { octasiloxane, } \\
1,1,3,3,5,5,7,7,9,9,11,11,13,13,15,15 \text {-hexadecamethyl- }\end{array}$ \\
\hline 58 & 29.9051 & 0.40 & $\gamma$-sitosterol \\
\hline
\end{tabular}

It is worth noting that the flavoring phenols found in the hydroalcoholic extracts from R. tinctorum (guaiacol, 4-vinyl-guaiacol and cis-eugenol) were the same present in oak, which are used to confer aroma to wine.

\subsection{Antifungal Activity}

\subsubsection{In vitro Tests of Mycelial Growth Inhibition}

The results of the mycelial growth inhibition tests for the hydromethanolic $R$. tinctorum root extract, alone or forming a conjugate complex with COS or stevioside, are presented in Figure 2 and Figures S2-S4. The antifungal activity of the extract was found to be much higher than those of COS and stevioside alone, reaching full inhibition at concentrations in the $93.8-250 \mu \mathrm{g} \cdot \mathrm{mL}^{-1}$ range, depending on the pathogen (vs. $1500 \mu \mathrm{g} \cdot \mathrm{mL}^{-1}$ for COS and stevioside). Upon conjugation with stevioside, some improvement in the germicide effect could be observed: for instance, the inhibition of $D$. seriata was higher at the $78.1 \mu \mathrm{g} \cdot \mathrm{mL}^{-1}$ concentration $(76.3 \%$ vs. $45.9 \%)$, and the full inhibition of $D$. viticola and $N$. parvum was attained at a lower concentration $\left(93.8 \mathrm{vs} .125 \mu \mathrm{g} \cdot \mathrm{mL}^{-1}\right.$, and $125 \mathrm{vs}$. $250 \mu \mathrm{g} \cdot \mathrm{mL}^{-1}$, respectively). Nonetheless, the best results were obtained for the COS $-R$. tinctorum extracts, for which full inhibition was recorded at the lowest concentrations (in the $70.3-78.1 \mu \mathrm{g} \cdot \mathrm{mL}^{-1}$ range).

In order to provide a tentative explanation for the strong antifungal activity observed in the extracts, three of the presumably bioactive constituents were also assayed (an anthracenedione, a phenol and a purine nucleoside) separately. The results, presented in Figures S5-S8, showed that 4-tert-butyl-2-phenylphenol was the most active (full inhibition of the three fungi was attained at concentrations in the $78.1-93.8 \mu \mathrm{g} \cdot \mathrm{mL}^{-1}$ range), but $1,2,4-$ trihydroxyanthraquinone and guanosine were also effective (full inhibition was reached at concentrations in the $187.5-500$ and $250-375 \mu \mathrm{g} \cdot \mathrm{mL}^{-1}$ ranges, respectively). Such values are comparable to those found for the whole $R$. tinctorum extract, suggesting that the activity cannot be ascribed to a single constituent, but rather to the combination of several of them.

To quantify the synergistic behavior observed for the conjugate complexes, effective concentrations were estimated (Table 4) and synergy factors (SF) were then calculated according to Wadley's method (Table 5). As expected, the synergism between COS and $R$. tinctorum extract was noticeably higher than the one observed between stevioside and $R$. tinctorum extract, with SF values in the 2.23-5.35 and 1.36-3.29 range, respectively.

\subsubsection{Assays on Autoclaved Grapevine Wood}

The results from the ex situ experiment conducted on autoclaved grapevine canes for the most promising treatment (COS-R. tinctorum conjugate complex) and the least sensitive fungus (D. seriata), presented in Table 6, showed that the application of the bioactive product led to statistically significant differences in terms of vascular necroses vs. the positive control. Nonetheless, it did not lead to full inhibition, given that there 
were statistically significant differences in the length of vascular lesions compared with the negative control (shoots inoculated only with the bioactive compound). This could be tentatively attributed to the chosen dispersion medium (agar), which was replaced with calcium alginate in subsequent in vivo experiments.
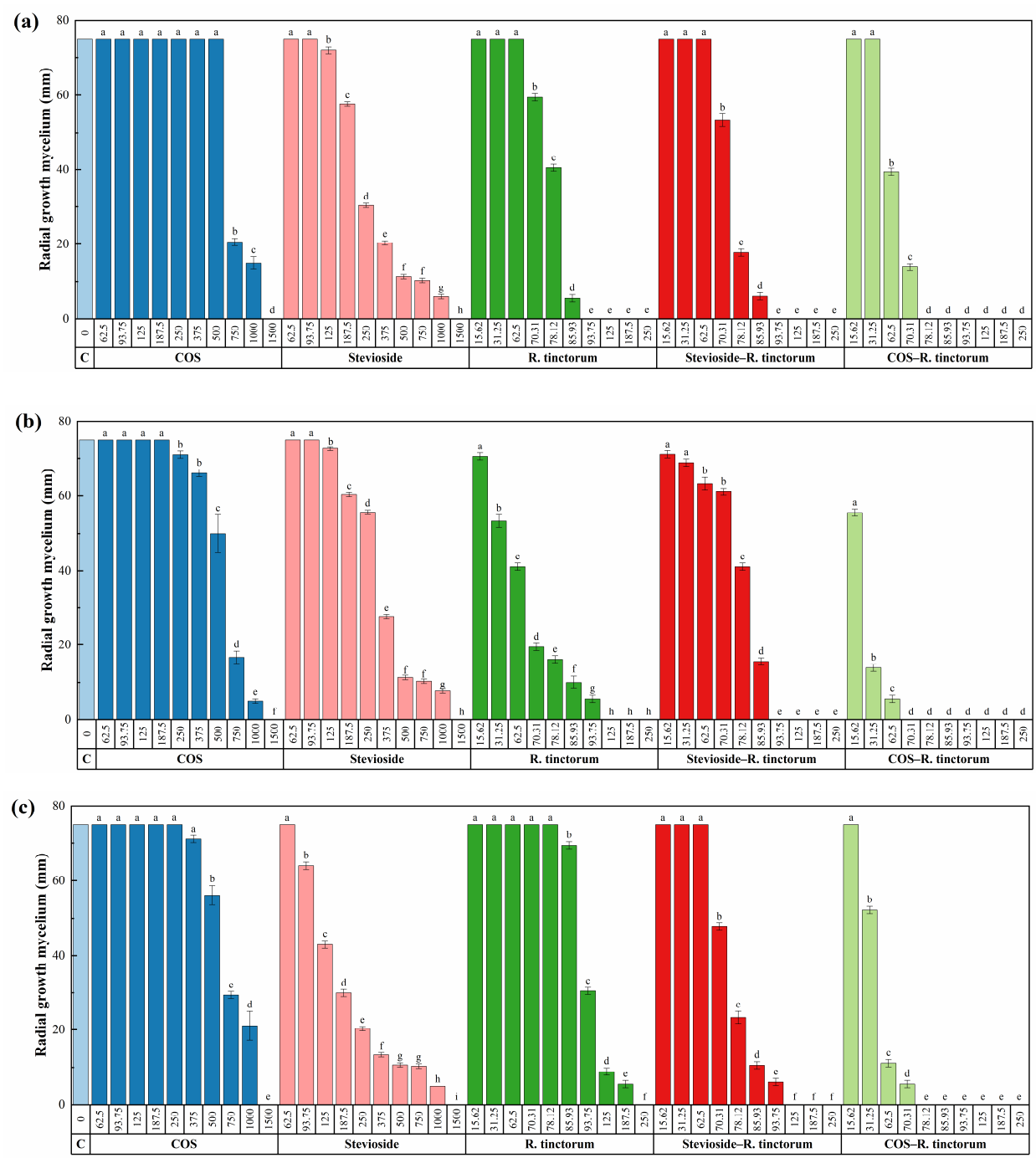

Figure 2. Colony growth measures of (a) D. seriata, (b) D. viticola and (c) N. parvum strains when cultured in PDA plates containing the various control products (viz. chitosan oligomers (COS), stevioside, $R$. tinctorum hydromethanolic extract, stevioside $-R$. tinctorum and COS- $R$. tinctorum conjugate complexes) at concentrations in the 62.5-1500 and $15.62-250 \mu \mathrm{g} \cdot \mathrm{mL}^{-1}$ range ordered according to the least and the most active products, respectively. The same letters above concentrations indicate that they are not significantly different at $p<0.05$. Error bars represent standard deviations.

Table 4. $\mathrm{EC}_{50}$ and $\mathrm{EC}_{90}$ effective concentrations. Values are expressed in $\mu \mathrm{g} \cdot \mathrm{mL}^{-1}$, and are followed by the standard errors of fit.

\begin{tabular}{|c|c|c|c|c|c|c|c|c|c|}
\hline Pathogen & EC & cos & Stevioside & R. tinctorum & $\begin{array}{c}\text { COS- } \\
\text { R. tinctorum }\end{array}$ & $\begin{array}{l}\text { Stevioside- } \\
\text { R. tinctorum }\end{array}$ & 4 -tert ... & $\begin{array}{c}1,2,4- \\
\text { trihydro } \\
\ldots\end{array}$ & Guanosine \\
\hline \multirow{2}{*}{ D. seriata } & $\mathrm{EC}_{50}$ & $744.4 \pm 43.9$ & $288.1 \pm 15.3$ & $78.0 \pm 0.8$ & $63.1 \pm 0.3$ & $73.6 \pm 0.3$ & $53.0 \pm 2.1$ & $45.4 \pm 3.4$ & $130.4 \pm 12.8$ \\
\hline & $\mathrm{EC}_{90}$ & $1179.9 \pm 58.2$ & $840.5 \pm 62.3$ & $87.8 \pm 1.9$ & $73.4 \pm 0.9$ & $82.4 \pm 0.7$ & $73.2 \pm 2.3$ & $\begin{array}{l}17.4 \pm 18.7 \\
171.4\end{array}$ & $249.9 \pm 28.5$ \\
\hline \multirow{2}{*}{ D. viticola } & $\mathrm{EC}_{50}$ & $554.3 \pm 27.4$ & $306.9 \pm 26.6$ & $66.2 \pm 2.9$ & $22.1 \pm 1.4$ & $80.0 \pm 0.7$ & $25.7 \pm 3.6$ & $37.2 *$ & $182.7 \pm 7.7$ \\
\hline & $\mathrm{EC}_{90}$ & $1138.7 \pm 75.0$ & $917.0 \pm 74.3$ & $90.2 \pm 8.7$ & $55.5 \pm 4.6$ & $90.7 \pm 1.5$ & $71.2 \pm 9.0$ & $74.9 *$ & $308.1 \pm 23.7$ \\
\hline \multirow{2}{*}{ N. paroum } & $\mathrm{EC}_{50}$ & $680.2 \pm 43.1$ & $194.8 \pm 13.4$ & $92.3 \pm 0.5$ & $38.2 \pm 1.4$ & $75.1 \pm 0.8$ & $62.2 \pm 0.7$ & $72.0 \pm 14.8$ & $95.1 \pm 22.6$ \\
\hline & EC 90 & $1326.6 \pm 83.2$ & $723.8 \pm 56.7$ & $184.0 \pm 1.1$ & $66.3 \pm 4.2$ & $89.2 \pm 1.9$ & $70.6 \pm 2.2$ & $338.4 \pm 37.9$ & $317.8 \pm 33.9$ \\
\hline
\end{tabular}

* Could not be reliably calculated (lack of points). 
Table 5. Synergy factors, estimated according to Wadley's method.

\begin{tabular}{|c|c|c|c|}
\hline \multirow{2}{*}{ Pathogen } & \multirow{2}{*}{ EC } & \multicolumn{2}{|c|}{ Synergy Factor } \\
\hline & & COS-R. tinctorum & Stevioside-R. tinctorum \\
\hline \multirow{2}{*}{ D. seriata } & $\mathrm{EC}_{50}$ & 2.24 & 1.67 \\
\hline & $\mathrm{EC}_{90}$ & 2.23 & 1.93 \\
\hline \multirow{2}{*}{ D. viticola } & $\mathrm{EC}_{50}$ & 5.35 & 1.36 \\
\hline & $\mathrm{EC}_{90}$ & 3.01 & 1.81 \\
\hline \multirow{2}{*}{ N. parvum } & $\mathrm{EC}_{50}$ & 4.26 & 1.67 \\
\hline & $\mathrm{EC}_{90}$ & 4.87 & 3.29 \\
\hline
\end{tabular}

Table 6. Kruskal-Wallis test and multiple pairwise comparisons using the Conover-Iman procedure for the lengths of the vascular necroses scored for $D$. seriata in the ex situ autoclaved grapevine canes assay.

\begin{tabular}{|c|c|c|c|c|c|c|}
\hline Sample & Frequency & Sum of Ranks & Mean of Ranks & & Groups & \\
\hline COS- $R$. tinctorum negative control & 24 & 300.000 & 12.500 & A & & \\
\hline COS-R. tinctorum-D. seriata & 120 & $10,193.000$ & 84.942 & & B & \\
\hline Positive control & 24 & 3703.000 & 154.292 & & & C \\
\hline
\end{tabular}

Treatments/controls labelled with the different letters are significantly different at $p<0.05$.

\subsubsection{Greenhouse Bioassays on Grafted Plants}

When the best treatment (COS-R. tinctorum conjugate complex) was further assayed in vivo, significant differences were found against the positive controls in all cases (Table 7), confirming its antifungal behavior on the plant material. Nonetheless, complete inhibition was not reached against any of the three pathogens for the assayed dose $\left(100 \mu \mathrm{g} \cdot \mathrm{mL}^{-1}\right)$ comparing with non-infected controls, suggesting that a higher concentration than the EC $_{90}$ values found in the in vitro tests (and/or a different dispersion medium) should be assayed when the treatment is used in future field trials.

Table 7. Kruskal-Wallis test and multiple pairwise comparisons using the Conover-Iman procedure for the lengths of the vascular necroses for the three phytopathogen in greenhouse in vivo assays.

\begin{tabular}{|c|c|c|c|c|c|c|c|}
\hline Pathogen & Sample & Frequency & Sum of Ranks & Mean of Ranks & & Groups & \\
\hline \multirow{3}{*}{ D. seriata } & COS-R. tinctorum negative control & 32 & 725.500 & 22.672 & A & \multirow{3}{*}{ B } & \\
\hline & COS-R. tinctorum-D. seriata & 72 & 6124.000 & 85.056 & & & \\
\hline & Positive control & 56 & 6030.500 & 107.688 & & & $\mathrm{C}$ \\
\hline \multirow{3}{*}{ D. viticola } & COS-R. tinctorum negative control & 32 & 1295.000 & 40.469 & A & \multirow{3}{*}{ B } & \\
\hline & COS-R. tinctorum-D. viticola & 72 & 4885.000 & 67.847 & & & \\
\hline & Positive control & 64 & 8016.000 & 125.250 & & & $\mathrm{C}$ \\
\hline \multirow{3}{*}{ N. paroum } & COS-R. tinctorum negative control & 32 & 572.000 & 17.875 & A & \multirow{3}{*}{ B } & \\
\hline & COS-R. tinctorum-N. parvum & 48 & 3695.000 & 76.979 & & & \\
\hline & Positive control & 64 & 6173.000 & 96.453 & & & C \\
\hline
\end{tabular}

Treatments/controls labelled with the different letters are significantly different at $p<0.05$.

\section{Discussion}

\subsection{On the Constituents of R. tinctorum Extracts}

The composition here reported was different from that found by Derksen and Van Beek [35] (using LC-DAD and HPLC-MS(/MS) with ESI or APCI), where lucidin primeveroside and ruberythric acid were the major anthraquinone components in an ethanolic-water extract, and from the one reported by Jalill [18] for a methanolic extract, which was rich in 9,12-octadecadienoic acid (29.75\%), 9-octadecenoic acid hexadecyl ester $(26.1 \%)$ and 2-ethyl-2-(hydroxymethyl)-1,3-propanediol, (10.1\%), but poor in anthracenediones (4.0\%) and 2-methoxy-4-vinylphenol (0.5\%). 
Significant differences in composition were also observed in comparison with the Rubia cordifolia essential oil characterized by GC-MS, in which mollugin (rubimaillin or methyl 6-hydroxy-2,2-dimethylbenzo[h]chromene-5-carboxylate) was found to be the major component, followed by 3-methyl-2-cyclopenten-1-one, eugenol, anethole and 4-tertbutyl-2-phenylphenol $[10,11]$.

Although the geographical location, time of year and age of the plant are known to influence the composition [15], the observed differences should be mainly ascribed to differences in both the extractive chemicals and in the extraction process (nature of the alcoholic solvent, alcohol:water ratio and mechanical enhancers such as sonication [36,37]), and to the characterization technique, provided that previous studies on $R$. tinctorum extracts [36,38-41] were conducted by HPLC and LC-HRMS (instead of GC-MS) and generally focused only on anthraquinones, anthraquinone glycosides and aglycones.

\subsection{On the Combined Effect of Anthraquinones and Phenols}

It is known that increasing the activity of a parent molecule can be pursued either by testing multiple substituent changes on the base core (the impact of the number, nature, and location of substituents on the anthraquinone moiety on its inhibitory potency against pathogenic fungi has been studied in [42]), or by testing the effect of coexistence with other molecules with which synergistic behavior may occur. In general, anthraquinone per se is a relatively inert compound, but in the presence of glucose, anthrahydroquinone units (formed by reduction of anthraquinone) reduce the quinone-methide units (issued by dehydration of phenolic $\beta-O-4$ lignin) mainly by electron transfer leading to guaiacol [43]. Thus, the presence of 4-vinyl-guaiacol, cis-eugenol, coniferyl alcohol or 4-tertbutyl-2-phenylphenol phytochemicals in the R. tinctorum hydromethanolic extract should be referred to the same origin. As regards a subsequent interaction of these phenols with anthraquinones, it cannot be excluded: Maurino et al. [44] have demonstrated that quinonoid compounds excited by sunlight react with phenols, transforming them into tetrasubstituted dihydroxybiphenyls and phenoxyphenols. Nevertheless, in the absence of induced sunlight, no reaction between anthraquinones and methoxy- and phenyl-phenols has been described in the literature (to the best of the authors' knowledge), so at this point it is not possible to establish whether the activity of $R$. tinctorum extracts may be referred to an additive effect of both families of components or to a synergistic one.

\subsection{Comparison with Efficacies Reported in the Literature}

An overview of the antimicrobial activities reported for R. tinctorum in the literature is presented in Table S2. Concerning its antifungal behavior, full inhibition of Aspergillus flavus Link and Fusarium oxysporum Schltdl. at a concentration of $100 \mu \mathrm{g} \cdot \mathrm{mL}^{-1}$ has been reported by Kalyoncu, et al. [45], and inhibition percentages in the $18-43 \%$ range were reported against Trichoderma viride Pers., Doratomyces stemonitis (Pers.) Nees, Aspergillus niger, Penicillium verrucosum Dierckx, Alternaria alternate (Fr.) Keissl., Aureobasidium pullulans (de Bary) G. Arnaud and Mucor mucedo L. by Manojlovic et al. [46], although the assayed concentration was not reported. Activity against other fungi (e.g., Penicillium expansum Link, Geotrichum candidum Link, Fusarium solani (Mart.) Sacc., Postia placenta (Fr.) M.J. Larsen and Lombard, Trametes versicolor (L.) Lloyd) has also been reported, albeit not in a quantitative manner $[47,48]$.

The contribution of anthraquinones to antifungal activity is well-established, given that anthracenediones from other plants have proven to be effective against a wide variety of phytopathogenic fungi. For instance, anthraquinones isolated from Cassia tora L., Coccoloba mollis Casar., Rheum palmatum L., Morinda lucida Benth. or Aegle marmelos (L.) Corrêa, to name a few, showed antifungal behavior against phytopathogenic fungi such as Botrytis cinerea, Blumeria graminis (DC.) Speer, Phytophthora infestans (Mont.) de Bary, Puccinia recondita Roberge ex Desm., Pyricularia grisea Sacc., Rhizoctonia solani J.G. Kühn, Botryospheria ribis Grossenbacher and Duggar, B. rhodina (Berk. and M.A. Curtis) Arx, Lasiodiplodia theobromae (Pat.) Griffon and Maubl., Fusarium sp., Fusarium graminearum 
Schwabe, Mycosphaerella melonis (Pass.) W.F. Chiu and J.C. Walker, Fusarium oxysporum f. sp. vasinfectum (G.F. Atk.) W.C. Snyder and H.N. Hansen, Phyllosticta zeae Stout, Sclerotinia sclerotiorum (Lib.) de Bary, Cladosporium cucumerinum Ellis and Arthur and Aspergillus spp. [49-53]. The underlying mechanism of action has been studied, for example, for purpurin against Candida spp., finding that it elevates intracellular ROS levels, depolarizes the mitochondrial membrane potential, downregulates of the expression of hypha-specific genes and the central morphogenetic regulator Ras1p and degrades DNA [54,55].

On the other hand, the antifungal activities of 2-methoxy- and 2-tert-butyl-substituted phenols against phytopathogens have been less studied, although a strong antifungal activity of 2-methoxy-4-(1-propenyl)-phenol against Botrytis cinerea was reported by Wang et al. [12]; against $B$. rhodina, Rhizoctonia sp. and Alternaria sp. by de Oliveira Pereira et al. [56]; and against $A$. alternata (Fr.) Keissl., Sarocladium oryzae (Sawada) W. Gams and D. Hawksw., F. graminearum, F. equiseti (Corda) Sacc. and F. verticillioides (Sacc.) Nirenberg by Pilar Santamarina et al. [57]. Likewise, 2-methoxy-phenol was effective against sap-staining fungi (Ophiostoma spp.), according to Velmurugan et al. [13]. Regarding their mechanism of action, it has been proposed that, for instance, eugenol acts on cell membrane by a mechanism that seems to involve the inhibition of ergosterol biosynthesis, and the lower ergosterol content interferes with the integrity and functionality of the cell membrane [56]. It has also been suggested that, taking into consideration that it induced the generation of $\mathrm{H}_{2} \mathrm{O}_{2}$ and increased free $\mathrm{Ca}^{2+}$ in the cytoplasm, its activity may also be referred to membrane binding and permeability alteration, leading to the destabilization and disruption of the plasma membrane [12].

\subsection{On the Synergistic Behaviour of R. tinctorum Extracts with COS and Stevioside}

To date, it has been verified that chitosan acts as an elicitor on $R$. tinctorum, stimulating anthraquinone synthesis [58]; chitosan/poly (lactic acid) nanoparticles have been evaluated as a novel carrier for the delivery of anthraquinone [59]; and chitosan-based hydrogels have been studied for the adsorption of anthraquinone dyes [60]. Nonetheless, after a thorough bibliographical survey, no previous examples of the use of chitosan or stevioside for the formation of conjugate complexes with anthraquinones could be found.

On the other hand, examples of synergistic behaviour have been reported, for instance, for chitosan combined with Cinnamomum zeylanicum Blume essential oils, rich in eugenol [61]. These authors hypothesized that eugenol alters the surface and structure of the fungal cell wall, and COS acts as a potentiator by reducing cell wall synthesis and facilitating death in an energy-dependent manner. In this regard, the accepted and potential mechanisms of action behind the antimicrobial properties of chitosan have been thoroughly discussed in the review paper by Ma et al. [62]. Those of stevioside have been discussed in [63], and are related to the uncoupling of mitochondrial oxidative phosphorylation and the permeabilization of the cell membrane.

Nonetheless, taking into consideration that the antifungal activity of both COS and stevioside alone was substantially lower than that of the $R$. tinctorum extract, and given that the use of most free anthraquinones in pharmaceutical industries is limited by their poor water solubility and low bioavailability [64], the observed strong synergistic behavior with COS and stevioside should probably be referred to a solubility and bioavailability enhancement through the formation of inclusion compounds or conjugate complexes (discussed, in the case of chitosan, in the recent review paper by Detsi et al. [65] and, for steviol glycosides, in the works by Nguyen et al. [66,67]). Examples of antifungal activity enhancement via the formation of conjugate complexes against GTDs have been previously reported in $[25,26,68]$, albeit with worse $\mathrm{EC}_{50}$ and $\mathrm{EC}_{90}$ values than those reported in this work.

\section{Conclusions}

The GC-MS analysis of $R$. tinctorum hydroalcoholic extracts revealed that, apart from members of the anthraquinone family $(19.4 \%)$, flavoring phenols similar to those found in 
oak (used to confer aroma to wine) and guanosine were also present. R. tinctorum extract, alone and forming conjugate complexes with COS and stevioside, along with three of its constituents, were assayed in vitro against three Botryosphaeriaceae taxa. R. tinctorum extract led to a strong mycelial growth inhibitory effect in all cases, with $\mathrm{EC}_{90}$ values as $88 \mu \mathrm{g} \cdot \mathrm{mL}^{-1}$. Although 4-tert-butyl-2-phenylphenol was its most active constituent, 1,2,4-trihydroxyanthraquinone and guanosine were also effective, suggesting the activity cannot be ascribed to a single constituent, but rather to the combination of several of them. As regards the strong synergistic behavior observed upon conjugation with COS, which resulted in $\mathrm{EC}_{90}$ values in the $56-73 \mu \mathrm{g} \cdot \mathrm{mL}^{-1}$ range, it may be ascribed to solubility and bioavailability enhancement, rather than to the antifungal activity of chitosan (which is much weaker than that of $R$. tinctorum). The treatment for which the best results were attained in plate tests (COS- $R$. tinctorum conjugate complex) was then tested ex situ on autoclaved grapevine twigs and in young, grafted plants in greenhouse assays. A significant reduction in the infection rate was found in all cases. Hence, this natural antifungal compound may deserve further examination in larger field trials, as it may be hold promise for the sustainable control of GTDs.

Supplementary Materials: The following are available online at https:/ /www.mdpi.com/article/10.3 390/plants10081527/s1, Table S1. Repetitions for each of the plant/treatment combinations in the greenhouse bioassay. Each grafted plant was inoculated at two sites below grafting point; Table S2. Examples of application of R. tinctorum extracts against microorganisms reported in the literature; Figure S1. GCMS spectrum of $R$. tinctorum root hydromethanolic extract; Figures S2-S4. Mycelial growth inhibition of D. seriata/D. viticola/N. parvum upon treatment with: chitosan oligomers, stevioside, $R$. tinctorum hydromethanolic extract, stevioside- $R$. tinctorum conjugate complex, and COS-R. tinctorum conjugate complex at different concentrations; Figure S5. Colony growth measures of D. seriata, D. viticola and N. parvum strains when cultured in PDA plates containing the main phytochemicals found in R. tinctorum hydromethanolic extracts at concentrations in the $62.5-1500$ and $15.62-250 \mu \mathrm{g} \cdot \mathrm{mL}^{-1}$ range for the least and the most active products, respectively; Figures S6-S8. Mycelial growth inhibition of D. seriata/D. viticola $/ N$. parvum upon treatment with the main phytochemicals found in R. tinctorum hydromethanolic extracts: purpurin, guanosine, and 4-tert-butyl-2-phenylphenol, at different concentrations.

Author Contributions: Conceptualization, J.M.-G., P.M.-R. and V.G.-G.; methodology, J.M.-G., J.C.-G. and V.G.-G.; validation, J.C.-G., V.G.-G. and P.M.-R.; formal analysis, J.C.-G., V.G.-G. and P.M.-R.; investigation, N.L.-L., E.S.-H., L.B.-D., V.G.-G., J.C.-G., J.M.-G. and P.M.-R.; resources, J.M.-G. and P.M.-R.; data curation, J.C.-G.; writing-original draft preparation, N.L.-L., E.S.-H., L.B.-D., V.G.-G., J.C.-G., J.M.-G. and P.M.-R.; writing-review and editing, V.G.-G. and P.M.-R.; visualization, N.L-L. and E.S.-H.; supervision, V.G.-G. and P.M.-R.; project administration, V.G.-G., J.M.-G. and P.M.-R.; funding acquisition, J.M.-G. and P.M.-R. All authors have read and agreed to the published version of the manuscript.

Funding: This research was funded by Junta de Castilla y León under project VA258P18, with FEDER co-funding; by Cátedra Agrobank under the "IV Convocatoria de Ayudas de la Cátedra AgroBank para la transferencia del conocimiento al sector agroalimentario" program and by Fundación IbercajaUniversidad de Zaragoza under the "Convocatoria Fundación Ibercaja-Universidad de Zaragoza de proyectos de investigación, desarrollo e innovación para jóvenes investigadores" program.

Data Availability Statement: The data presented in this study are available on request from the corresponding author. The data are not publicly available due to their relevance to an ongoing Ph.D. thesis.

Acknowledgments: V.G.-G thanks C. Julián (Plant Protection Unit, CITA) for her technical assistance. The authors gratefully acknowledge the support of Pilar Blasco and Pablo Candela at the Servicios Técnicos de Investigación, Universidad de Alicante, for conducting the GC-MS analyses.

Conflicts of Interest: The authors declare no conflict of interest. The funders had no role in the design of the study; in the collection, analyses, or interpretation of data; in the writing of the manuscript, or in the decision to publish the results. 


\section{References}

1. Qiu, H.; Liu, R.; Long, L. Analysis of chemical composition of extractives by acetone and the chromatic aberration of teak (Tectona Grandis L.F.) from China. Molecules 2019, 24, 1989. [CrossRef] [PubMed]

2. Murdock, K.C.; Child, R.G.; Fabio, P.F.; Angier, R.D.; Wallace, R.E.; Durr, F.E.; Citarella, R.V. Antitumor agents. 1. 1,4Bis[(aminoalkyl)amino]-9,10-anthracenediones. J. Med. Chem. 1979, 22, 1024-1030. [CrossRef] [PubMed]

3. Coufal, N.; Farnaes, L. Anthracyclines and anthracenediones. In Cancer Management in Man: Chemotherapy, Biological Therapy, Hyperthermia and Supporting Measures; Minev, B., Ed.; Springer: Dordrecht, The Netherlands, 2011; pp. 87-102. [CrossRef]

4. Wuthi-udomlert, M.; Kupittayanant, P.; Gritsanapan, W. In vitro evaluation of antifungal activity of anthraquinone derivatives of Senna alata. J. Health Res. 2010, 24, 117-122.

5. Agarwal, S.; Singh, S.S.; Verma, S.; Kumar, S. Antifungal activity of anthraquinone derivatives from Rheum emodi. J. Ethnopharmacol. 2000, 72, 43-46. [CrossRef]

6. Singh, D.; Verma, N.; Raghuwanshi, S.; Shukla, P.; Kulshreshtha, D. Antifungal anthraquinones from Saprosma fragrans. Bioorg. Med. Chem. Lett. 2006, 16, 4512-4514. [CrossRef]

7. Singh, J.; Hussain, Y.; Luqman, S.; Meena, A. Purpurin: A natural anthraquinone with multifaceted pharmacological activities. Phytother. Res. 2020, 35, 2418-2428. [CrossRef]

8. Essaidi, I.; Snoussi, A.; Koubaier, H.B.H.; Casabianca, H.; Bouzouita, N. Effect of acid hydrolysis on alizarin content, antioxidant and antimicrobial activities of Rubia tinctorum extracts. Pigment. Resin Technol. 2017, 46, 379-384. [CrossRef]

9. Ilc, T.; Werck-Reichhart, D.; Navrot, N. Meta-analysis of the core aroma components of grape and wine aroma. Front. Plant Sci. 2016, 7, 1472. [CrossRef]

10. Miyazawa, M.; Kawata, J. Identification of the key aroma compounds in dried roots of Rubia cordifolia. J. Oleo Sci. 2006, 55, 37-39. [CrossRef]

11. Li, W.-Q.; Quan, M.-P.; Li, Q. Chemical composition and antibacterial activity of the essential oil from Qiancao (Rubia cordifolia Linn.) roots against selected foodborne pathogens. Asian J. Agric. Food Sci. 2019, 7. [CrossRef]

12. Wang, C.; Zhang, J.; Chen, H.; Fan, Y.; Shi, Z. Antifungal activity of eugenol against Botrytis cinerea. Trop. Plant Pathol. 2010, 35, 137-143. [CrossRef]

13. Velmurugan, N.; Han, S.S.; Lee, Y.S. Antifungal activity of neutralized wood vinegar with water extracts of Pinus densiflora and Quercus serrata saw dusts. Int. J. Environ. Res. 2009, 3, 167-176. [CrossRef]

14. Singh, R.; Chauhan, S.M.S.G. 9,10-Anthraquinones and other biologically active compounds from the GenusRubia. Chem. Biodivers. 2004, 1, 1241-1264. [CrossRef]

15. Angelini, L.G.; Pistelli, L.; Belloni, P.; Bertoli, A.; Panconesi, S. Rubia tinctorum a source of natural dyes: Agronomic evaluation, quantitative analysis of alizarin and industrial assays. Ind. Crop. Prod. 1997, 6, 303-311. [CrossRef]

16. Boldizsár, I.; Szücs, Z.; Füzfai, Z.; Molnár-Perl, I. Identification and quantification of the constituents of madder root by gas chromatography and high-performance liquid chromatography. J. Chromatogr. A 2006, 1133, 259-274. [CrossRef]

17. Nakanishi, F.; Nagasawa, Y.; Kabaya, Y.; Sekimoto, H.; Shimomura, K. Characterization of lucidin formation in Rubia tinctorum L. Plant Physiol. Biochem. 2005, 43, 921-928. [CrossRef]

18. Jalill, R.D.A. GC-MS analysis of extract of Rubia tinctorum having anticancer properties. Int. J. Pharmacogn. Phytochem. Res. 2017, 9, 286-292.

19. Úrbez-Torres, J.R.; Hrycan, J.; Hart, M.; Bowen, P.; Forge, T. Grapevine trunk disease fungi: Their roles as latent pathogens and stress factors that favour disease development and symptom expression. Phytopathol. Mediterr. 2020, 59, 395-424. [CrossRef]

20. Bertsch, C.; Ramírez-Suero, M.; Magninrobert, M.; Larignon, P.; Chong, J.; Mansour, E.A.; Spagnolo, A.; Clément, C.; Fontaine, F. Grapevine trunk diseases: Complex and still poorly understood. Plant Pathol. 2012, 62, 243-265. [CrossRef]

21. Gramaje, D.; Armengol, J. Fungal Trunk pathogens in the grapevine propagation process: Potential inoculum sources, detection, identification, and management strategies. Plant Dis. 2011, 95, 1040-1055. [CrossRef]

22. Fontaine, F.; Gramaje, D.; Armengol, J.; Smart, R.; Nagy, Z.A.; Borgo, M.; Rego, C.; Corio-Costet, M.-F. Grapevine Trunk Diseases: A Review; OIV Publications: Paris, France, 2016; p. 25.

23. Mondello, V.; Songy, A.; Battiston, E.; Pinto, C.; Coppin, C.; Trotel-Aziz, P.; Clément, C.; Mugnai, L.; Fontaine, F. Grapevine trunk diseases: A review of fifteen years of trials for their control with chemicals and biocontrol agents. Plant Dis. 2018, 102, 1189-1217. [CrossRef] [PubMed]

24. Gramaje, D.; Úrbez-Torres, J.R.; Sosnowski, M.R. Managing grapevine trunk diseases with respect to etiology and epidemiology: Current strategies and future prospects. Plant Dis. 2018, 102, 12-39. [CrossRef] [PubMed]

25. Langa-Lomba, N.; Buzón-Durán, L.; Sánchez-Hernández, E.; Martín-Ramos, P.; Casanova-Gascón, J.; Martín-Gil, J.; GonzálezGarcía, V. Antifungal activity against Botryosphaeriaceae fungi of the hydro-methanolic extract of Silybum marianum capitula conjugated with stevioside. Plants 2021, 10, 1363. [CrossRef]

26. Langa-Lomba, N.; Buzón-Durán, L.; Martín-Ramos, P.; Casanova-Gascón, J.; Martín-Gil, J.; Sánchez-Hernández, E.; GonzálezGarcía, V. Assessment of conjugate complexes of chitosan and Urtica dioica or Equisetum arvense extracts for the control of grapevine trunk pathogens. Agronomy 2021, 11, 976. [CrossRef]

27. Nunn, S.; Nishikida, K. Advanced ATR Correction Algorithm-Application Note 50581; ThermoScientific: Madison, WI, USA, 2008 ; p. 4.

28. Adams, R.P. Identification of Essential Oil Components by Gas Chromatography/Mass Spectroscopy, 4th ed.; Allured Publishing Corp.: Carol Stream, IL, USA, 2007; p. 804. 
29. Santos-Moriano, P.; Fernandez-Arrojo, L.; Mengíbar, M.; Belmonte-Reche, E.; Peñalver, P.; Acosta, F.N.; Ballesteros, A.O.; Morales, J.C.; Kidibule, P.; Fernandez-Lobato, M.; et al. Enzymatic production of fully deacetylated chitooligosaccharides and their neuroprotective and anti-inflammatory properties. Biocatal. Biotransform. 2017, 36, 57-67. [CrossRef]

30. Buzón-Durán, L.; Martín-Gil, J.; Pérez-Lebeña, E.; Ruano-Rosa, D.; Revuelta, J.L.; Casanova-Gascón, J.; Ramos-Sánchez, M.C.; Martín-Ramos, P. Antifungal agents based on chitosan oligomers, $\varepsilon$-polylysine and streptomyces spp. secondary metabolites against three botryosphaeriaceae species. Antibiotics 2019, 8, 99. [CrossRef]

31. Martin, M.T.; Cobos, R. Identification of fungi associated with grapevine decline in Castilla y León (Spain). Phytdopathol. Mediterr. 2007, 46, 18-25. [CrossRef]

32. Arendrup, M.C.; Cuenca-Estrella, M.; Lass-Flörl, C.; Hope, W. EUCAST technical note on the EUCAST definitive document EDef 7.2: Method for the determination of broth dilution minimum inhibitory concentrations of antifungal agents for yeasts EDef 7.2 (EUCAST-AFST)* Clin. Microbiol. Infect. 2012, 18, E246-E247. [CrossRef]

33. Levy, Y.; Benderly, M.; Cohen, Y.; Gisi, U.; Bassand, D. The joint action of fungicides in mixtures: Comparison of two methods for synergy calculation. EPPO Bull. 1986, 16, 651-657. [CrossRef]

34. R Core Team. R: A Language and Environment for Statistical Computing; R Foundation for Statistical Computing: Vienna, Austria, 2020.

35. Derksen, G.C.H.; Van Beek, T.A. Rubia tinctorum L. In Studies in Natural Products Chemistry; Ur-Rahman, A., Ed.; Elsevier: Amsterdam, The Netherlands, 2002; Volume 26, pp. 629-684.

36. DE Santis, D.; Moresi, M. Production of alizarin extracts from Rubia tinctorum and assessment of their dyeing properties. Ind. Crop. Prod. 2007, 26, 151-162. [CrossRef]

37. Dulo, B.; Phan, K.; Githaiga, J.; Raes, K.; De Meester, S. Natural quinone dyes: A review on structure, extraction techniques, analysis and application potential. Waste Biomass Valoriz. 2021, 1-36. [CrossRef]

38. Derksen, G.; van Beek, T.A.; de Groot, Æ.; Capelle, A. High-performance liquid chromatographic method for the analysis of anthraquinone glycosides and aglycones in madder root (Rubia tinctorum L.). J. Chromatogr. A 1998, 816, 277-281. [CrossRef]

39. Derksen, G.C.H.; Lelyveld, G.P.; Van Beek, T.A.; Capelle, A. Two validated HPLC methods for the quanti?cation of alizarin and other anthraquinones inRubia tinctorum cultivars. Phytochem. Anal. 2004, 15, 397-406. [CrossRef]

40. Krizsán, K.; Szókán, G.; Tóth, Z.A.; Hollósy, F.; Laszlo, M.; Khlafulla, A. HPLC Analysis of Anthraquinone Derivatives in Madder Root (Rubia Tinctorum) and Its Cell Cultures. J. Liq. Chromatogr. Relat. Technol. 1996, 19, 2295-2314. [CrossRef]

41. Eltamany, E.E.; Nafie, M.S.; Khodeer, D.M.; El-Tanahy, A.; Abdel-Kader, M.S.; Badr, J.M.; Abdelhameed, R.F.A. Rubia tinctorum root extracts: Chemical profile and management of type II diabetes mellitus. RSC Adv. 2020, 10, 24159-24168. [CrossRef]

42. Friedman, M.; Xu, A.; Lee, R.; Nguyen, D.N.; Phan, T.A.; Hamada, S.M.; Panchel, R.; Tam, C.C.; Kim, J.H.; Cheng, L.W.; et al. The inhibitory activity of anthraquinones against pathogenic protozoa, bacteria, and fungi and the relationship to structure. Molecules 2020, 25, 3101. [CrossRef]

43. Megiatto, J.J.D.; Cazeils, E.; Ham-Pichavant, F.; Grelier, S.; Gardrat, C.; Castellan, A. Styrene-spaced copolymers including anthraquinone and $\beta-\mathrm{O}-4$ lignin model units: Synthesis, characterization and reactivity under alkaline pulping conditions Biomacromolecules 2012, 13, 1652-1662. [CrossRef]

44. Maurino, V.; Borghesi, D.; Vione, D.; Minero, C. Transformation of phenolic compounds upon UVA irradiation of anthraquinone2-sulfonate. Photochem. Photobiol. Sci. 2007, 7, 321-327. [CrossRef]

45. Kalyoncu, F.; Çetin, B.; Saglam, H. Antimicrobial activity of common madder (Rubia tinctorum L.). Phytother. Res. 2006, 20, 490-492. [CrossRef]

46. Manojlovic, N.; Solujic, S.; Sukdolak, S.; Milosev, M. Antifungal activity of Rubia tinctorum, Rhamnus frangula and Caloplaca cerina. Fitoterapia 2005, 76, 244-246. [CrossRef]

47. Mehrabian, S.; Majd, A.; Majd, I. Antimicrobial effects of three plants (rubia tinctorum, carthamus tinctorius and juglans regia) on some airborne microorganisms. Aerobiologia 2000, 16, 455-458. [CrossRef]

48. Ozen, E.; Yeniocak, M.; Goktas, O.; Alma, M.H.; Yilmaz, F. Antimicrobial and antifungal properties of madder root (Rubia tinctorum) colorant used as an environmentally-friendly wood preservative. Bioresources 2014, 9, 1998-2009. [CrossRef]

49. Kim, Y.-M.; Lee, C.-H.; Kim, A.H.-G.; Lee, H.-S. Anthraquinones isolated from Cassiatora (Leguminosae) seed show an antifungal property against phytopathogenic fungi. J. Agric. Food Chem. 2004, 52, 6096-6100. [CrossRef]

50. De Barros, I.B.; Daniel, J.F.D.S.; Pinto, J.P.; Rezende, M.I.; Filho, R.B.; Ferreira, D.T. Phytochemical and antifungal activity of anthraquinones and root and leaf extracts of Coccoloba mollis on phytopathogens. Braz. Arch. Biol. Technol. 2011, 54, 535-541. [CrossRef]

51. Shang, X.-F.; Zhao, Z.-M.; Li, J.-C.; Yang, G.-Z.; Liu, Y.-Q.; Dai, L.-X.; Zhang, Z.-J.; Yang, Z.-G.; Miao, X.-L.; Yang, C.-J.; et al. Insecticidal and antifungal activities of Rheum palmatum L. anthraquinones and structurally related compounds. Ind. Crop. Prod. 2019, 137, 508-520. [CrossRef]

52. Rath, G.; Ndonzao, M.; Hostettmann, K. Antifungal anthraquinones from Morinda lucida. Int. J. Pharmacogn. 1995, 33, 107-114. [CrossRef]

53. Mishra, B.B.; Kishore, N.; Tiwari, V.K.; Singh, D.D.; Tripathi, V. A novel antifungal anthraquinone from seeds of Aegle marmelos Correa (family Rutaceae). Fitoterapia 2010, 81, 104-107. [CrossRef]

54. Tsang, P.W.-K.; Bandara, H.; Fong, W.-P. Purpurin suppresses candida albicans biofilm formation and hyphal development. PLoS ONE 2012, 7, e50866. [CrossRef] 
55. Tsang, P.W.-K.; Wong, A.P.-K.; Yang, H.-P.; Li, N.-F. Purpurin triggers caspase-independent apoptosis in candida dubliniensis biofilms. PLoS ONE 2013, 8, e86032. [CrossRef]

56. Pereira, F.D.O.; Mendes, J.M.; Lima, E.D.O. Investigation on mechanism of antifungal activity of eugenol againstTrichophyton rubrum. Med. Mycol. 2013, 51, 507-513. [CrossRef]

57. Santamarina, M.P.; Roselló, J.; Giménez, S.; Blázquez, M.A. Commercial Laurus nobilis L. and Syzygium aromaticum L. Merr. \& Perry essential oils against post-harvest phytopathogenic fungi on rice. LWT 2016, 65, 325-332. [CrossRef]

58. Vasconsuelo, A.; Giulietti, A.M.; Boland, R. Signal transduction events mediating chitosan stimulation of anthraquinone synthesis in Rubia tinctorum. Plant Sci. 2004, 166, 405-413. [CrossRef]

59. Jeevitha, D.; Amarnath, K. Chitosan/PLA nanoparticles as a novel carrier for the delivery of anthraquinone: Synthesis, characterization and in vitro cytotoxicity evaluation. Coll. Surf. B Biointerf. 2013, 101, 126-134. [CrossRef] [PubMed]

60. Oladipo, A.A.; Gazi, M.; Yilmaz, E. Single and binary adsorption of azo and anthraquinone dyes by chitosan-based hydrogel: Selectivity factor and Box-Behnken process design. Chem. Eng. Res. Des. 2015, 104, 264-279. [CrossRef]

61. Mohammadi, A.; Hashemi, M.; Hosseini, S. The control of Botrytis fruit rot in strawberry using combined treatments of Chitosan with Zataria multiflora or Cinnamomum zeylanicum essential oil. J. Food Sci. Technol. 2015, 52, 7441-7448. [CrossRef]

62. Ma, Z.; Garrido-Maestu, A.; Jeong, K.C. Application, mode of action, and in vivo activity of chitosan and its micro- and nanoparticles as antimicrobial agents: A review. Carbohydr. Polym. 2017, 176, 257-265. [CrossRef]

63. Buzón-Durán, L.; Martín-Gil, J.; Ramos-Sánchez, M.D.C.; Pérez-Lebeña, E.; Marcos-Robles, J.L.; Fombellida-Villafruela, Á.; Martín-Ramos, P. Antifungal activity against Fusarium culmorum of stevioside, Silybum marianum seed extracts, and their conjugate complexes. Antibiotics 2020, 9, 440. [CrossRef]

64. Xu, H.; Lu, Y.; Zhang, T.; Liu, K.; Liu, L.; He, Z.; Xu, B.; Wu, X. Characterization of binding interactions of anthraquinones and bovine $\beta$-lactoglobulin. Food Chem. 2019, 281, 28-35. [CrossRef]

65. Detsi, A.; Kavetsou, E.; Kostopoulou, I.; Pitterou, I.; Pontillo, A.R.N.; Tzani, A.; Christodoulou, P.; Siliachli, A.; Zoumpoulakis, P. Nanosystems for the encapsulation of natural products: The case of chitosan biopolymer as a matrix. Pharmaceutics 2020, 12, 669. [CrossRef]

66. Nguyen, T.T.H.; Si, J.; Kang, C.; Chung, B.; Chung, D.; Kim, D. Facile preparation of water soluble curcuminoids extracted from turmeric (Curcuma longa L.) powder by using steviol glucosides. Food Chem. 2017, 214, 366-373. [CrossRef]

67. Nguyen, T.T.H.; Yu, S.-H.; Kim, J.; An, E.; Hwang, K.; Park, J.-S.; Kim, D. Enhancement of quercetin water solubility with steviol glucosides and the studies of biological properties. Funct. Foods Health Dis. 2015, 5, 437. [CrossRef]

68. Buzón-Durán, L.; Langa-Lomba, N.; González-García, V.; Casanova-Gascón, J.; Martín-Gil, J.; Pérez-Lebeña, E.; Martín-Ramos, P. On the applicability of chitosan oligomers-amino acid conjugate complexes as eco-friendly fungicides against grapevine trunk pathogens. Agronomy 2021, 11, 324. [CrossRef] 